9. Feili, H. R., Ahmadian, P. and Rabiei, E., Life cycle assessment of municipal solid waste systems to prioritize and compare their methods with multi-criteria decision making. OAJRE, 2014, 39, $1-12$.

10. Azhiri, R. B., Sola, J. F., Tekiyeh, R. M., Javidpour, F. and Bideskan, A. S., Analyzing of joint strength, impact energy, and angular distortion of the ABS friction stir welded joints reinforced by nanosilica addition. Int. J. Adv. Manuf. Technol., 2018, 1, 1-14.

11. Azhiri, R. B., Tekiyeh, R. M., Zeynali, E., Ahmadnia, M. and Javidpour, F., Measurement and evaluation of joint properties in friction stir welding of ABS sheets reinforced by nanosilica addition. Measurement, 2018, 127, 198-204.

12. Ketabchy, M., Sample, D. J., Wynn-Thompson, T. and Yazdi, M. N., Thermal evaluation of urbanization using a hybrid approach. J. Environ. Manage., 2018, 226, 457-475.

13. Joshaghani, M., Ghasemi-Fare, O. and Ghavami, M., Experimental investigation on the effects of temperature on physical properties of sandy soils. IFCEE, 2018, 1, 675-685.

14. Khodabandeh, E., Rozati, S. A., Joshaghani, M., Akbari, O. A., Akbari, S. and Toghraie, D., Thermal performance improvement in water nanofluid/GNP-SDBS in novel design of double-layer microchannel heat sink with sinusoidal cavities and rectangular ribs. J. Therm. Anal. Calorim., 2018, 1, 1-13.

15. Jafarzadeh, F., Jahromi, H. F., Yoosefi, S., Sehizadeh, M., Joshaghani, M. and Alavi, M., Dynamic response of buried gas pipelines due to earthquake induced landslides by nonlinear numerical modeling. In The 15th World Conference on Earthquake Engineering, Beijing, China (15WCEE), 2012.

16. Pourmand, G., Safavi, M., Ahmadi, A., Houdeh, E., Noori, M. Mashhadi, R. and Pourmand, N., A silver lining for early diagnosis of prostate cancer. Urol. J., 2016, 13, 2845-2848.

17. Bakhshi, H., Khodabandeh, E., Akbari, O., Toghraie, D., Joshaghani, M. and Rahbari, A., Investigation of laminar fluid flow and heat transfer of nanofluid in trapezoidal microchannel with different aspect ratios. Int. J. Numer. Method H., 2018, 1, 1-13.

18. Pirbazari, A. E., Monazzam, P. and Kisomi, B. F., Desalin. Co/ $\mathrm{TiO}_{2}$ nanoparticles: preparation, characterization and its application for photocatalytic degradation of methylene blue. Water Treat., 2017, 63, 283-292.

19. Ebrahimian Pirbazari, A., Fakhari Kisom, B. and Ghamangiz Khararoodi, M., Anionic surfactant-modified rice straw for removal of methylene blue from aqueous solution. Desalin. Water Treat., 2016, 57, 18202-18216.

20. Momtazan, M., Niyakan, M., Jaderi, T. and Hoseini Ahangari, S. A., The amount of scientific production of Ahvaz Jundishapur university of medical sciences on pubmed in 2000-2013. Res. J. Med. Sci., 2016, 10, 49-53.

21. Leopoldini, M., Marino, T., Russo, N. and Toscano, M., Antioxidant properties of phenolic compounds: H-atom versus electron transfer mechanism. J. Phys. Chem. A, 2004, 108, 4916-4922.

22. Nam, P. C., Nguyen, M. T. and Chandra, A. K., Assessment of the importance of changes in ground-state energies on the bond dissociation enthalpies of the $\mathrm{O}-\mathrm{H}$ bonds in phenols and the S-H bonds in thiophenols. J. Phys. Chem. A, 2006, 110, 1090410911.

23. Mohajeri, A. and Asemani, S. S., Theoretical investigation on antioxidant activity of vitamins and phenolic acids for designing a novel antioxidant. J. Mol. Struct: (Theochem), 2009, 930, 15-20.

24. Rimarcik, J., Lukes, V., Klein, E., Griesser, M. and Kelterer, A., Theoretical study of structure and electronic properties of cyanosubstituted pyrroles. Chem. Phys., 2008, 353, 177-184.

25. Brinck, T., Haeberline, M. and Jonsson, M., Theoretical study of $\mathrm{X}-\mathrm{H}$ bond energetics $(\mathrm{X}=\mathrm{C}, \mathrm{N}, \mathrm{O}, \mathrm{S})$ application to substituent effects, gas phase acidities, and redox potentials. J. Am. Chem. Soc., 1997, 119, 4239-4244.

26. Klein, E. and Lukes, V., Proton Affinities of para- and metasubstituted phenols in water. Chem. Phys., 2006, 330, 515-525.
27. Najafi, M., Zahedi, M. and Klein, E., DFT/B3LYP study of the solvent effect on the reaction enthalpies of homolytic and heterolytic $\mathrm{OH}$ bond cleavage in mono-substituted chromans. Comput. Theor. Chem., 2011, 978, 16-28.

28. Klein, E., Lukes, V. and Cibulkova, Z., Quantum-chemical study of $\mathrm{C}-\mathrm{H}$ bond dissociation enthalpies of various small non-aromatic organic molecules. J. Mol. Struct.: (Theo-chem.), 2006, 758, 149-159.

29. Kumar, D., Kumar, N. M. and Sundaree, S., A facile synthesis of novel bis-(indolyl)-1,3,4-oxadiazoles as potent cytotoxic agents. Eur. J. Med. Chem., 2010, 45, 1244-1249.

30. Sadasivam, K. and Kumaresan, R., Theoretical investigation on the antioxidant behavior of chrysoeriol and hispidulin flavonoid compounds a DFT study. Comput. Theor. Chem., 2011, 963, 227235 .

Received 8 May 2017; revised accepted 24 October 2018

doi: $10.18520 / \mathrm{cs} / \mathrm{v} 116 / \mathrm{i} 3 / 468-472$

\section{Allocation of biomass and carbon stocks in seven woody species of tropical deciduous forests, Dang, Gujarat}

\section{Ekta Purswani $^{1}$, Bhawana Pathak $^{1, *}$ and Harshad Salvi $^{2}$}

${ }^{1}$ School of Environment and Sustainable Development, Central University of Gujarat, Gandhinagar 382 030, India ${ }^{2}$ Gujarat Ecological Education and Research Foundation, Gandhinagar 382 007, India

Literature on the biomass estimates and carbon cycles of Asian tropical deciduous forests is very limited. In this study, seven woody species were selected, with four representatives each in chronosequence, and harvested from deciduous forests of Dang, Gujarat for assessing their biomass and carbon content. All the species showed a carbon percentage between $40 \%$ and $45 \%$. The regression equations of total biomass versus girth class developed for all seven species would be useful to estimate biomass on a larger scale and the carbon content would improve the understanding about carbon accounts of Indian forests.

Keywords: Biomass estimation, carbon sequestration, climate change, Indian forests, tropical deciduous forests.

ABOUT $17 \%$ of the global $\mathrm{CO}_{2}$ emissions occur due to deforestation and land-use change ${ }^{1}$. Reduction of emissions through deforestation and forest degradation (REDD+)

*For correspondence. (e-mail: bhawana.pathak@cug.ac.in) 


\section{RESEARCH COMMUNICATIONS}

was initiated by the United Nations Framework for Convention on Climate Change (UNFCCC) to minimize $\mathrm{CO}_{2}$ emissions by managing forests ${ }^{2}$. Hence, accounting carbon (henceforth C) stocks at regional and national levels is a major trial for REDD+ implementation around the world ${ }^{3}$. There still remain uncertainties in biomass and carbon stocks from the tropics as studies are few, incomplete and outdated ${ }^{4,5}$. Asia contains $58 \%$ of world's tropical deciduous forests while they form $60 \%$ of Indian forest cover. But in a review, Becknell et al. ${ }^{6}$ stated that only $9 \%$ of the data out of total 229 global studies covered Asia, suggesting the need for biomass and carbon estimates from India.

Destructive harvesting method provides us with actual data of biomass which is required to validate other indirect methods of biomass estimation, such as the use of non-destructive in-situ measurements, allometric models and remote sensing ${ }^{7,8}$. Short-lived components in a deciduous forest also contribute significantly to biomass production and nutrient cycling forming $62 \%$ of dry matter ${ }^{9}$. The perennial aerial structure, the roots and the foliage make up $82 \%, 14 \%$ and $4 \%$ of the total vegetation carbon density $^{9,10}$. Hence, we applied destructive tree harvesting method with apportionment of tree into seven components for above-ground biomass estimation. This study involved an inventory for biomass and carbon stock estimates. It is the first of its kind study in Gujarat after the Forest Survey of India did a forest resource survey in 1981 and published volume equations in 1996 (ref. 11).

Many studies have been published on above-ground biomass (AGB) estimates in tropical forests around the world whereas the volume of literature on below-ground biomass estimates in tropical areas is relatively small. Root biomass is commonly estimated from standard root to shoot biomass ratios which may be species- or biomespecific (coniferous versus deciduous) ${ }^{12}$. However, changes in tree biomass allometry may also affect allometric equations for root biomass and root to shoot biomass ratios. As below-ground biomass in tree roots may account for a significant portion of total forest biomass and may provide an additional important $\mathrm{C}$ pool, the inclusion and improvement of root biomass estimates is imperative ${ }^{12,13}$. This leads to underestimates of forest biomass and carbon stocks since the rest of the parts contribute significantly to forest biomass and thereby, leading to many uncertainties in forest carbon accounting. The most commonly used regression equation is that of a straight line

$$
(\ln \text { biomass })=a+b(\ln \mathrm{dbh}),
$$

where biomass is the $y$ (dependent) variable and the diameter at breast height (dbh) is the $x$ (independent) variable $e^{11,14}$.

In the present study, the woody species, viz. Adina cordifolia, Bridelia retusa, Casearia graveolens, Dalber- gia latifolia, Ougeinia oojeinensis, Schleichera oleosa and Terminalia bellirica have been selected for estimating their biomass, carbon content and carbon capturing potential. The purpose was to estimate the total biomass and carbon stocks of selected species. In this communication, an attempt has been made to derive a relationship between biomass and girth class by obtaining a regression equation of biomass versus girth class. Also, the variation of biomass of different parts of the plant with carbon content was determined. The knowledge of carbon stocks of tropical dry deciduous forests in Gujarat state thus obtained will be helpful further to analyse carbon fluxes in future.

The study site was selected from the Dang forests, also called as 'the Dangs' district in south Gujarat situated at lat. $20^{\circ} 33^{\prime} 50^{\prime \prime}$ and $21^{\circ} 04^{\prime} 52^{\prime \prime}$ and the meridians of long. $73^{\circ} 27^{\prime} 58^{\prime \prime}$ and $73^{\circ} 56^{\prime} 38^{\prime \prime}$ (Figure 1) ${ }^{15}$. The total area of the district is $1764 \mathrm{~km}^{2}$ comprising $77.4 \%$ of forest areas forming $1035.3521 \mathrm{~km}^{2}$ (ref. 16). Dang tract is hilly having Sahyadri mountains on the eastern side going up to about $1100 \mathrm{~m}$ which descend as one moves towards the west extending to the edge of plains of Gujarat. Hills are low and flat-topped in north and west directions. Most of the area in the Dangs lies between 300 and $700 \mathrm{~m}$ above mean sea level.

The Dang forests consist of mixed tree growth among which teak (locally sag) is the predominant species in

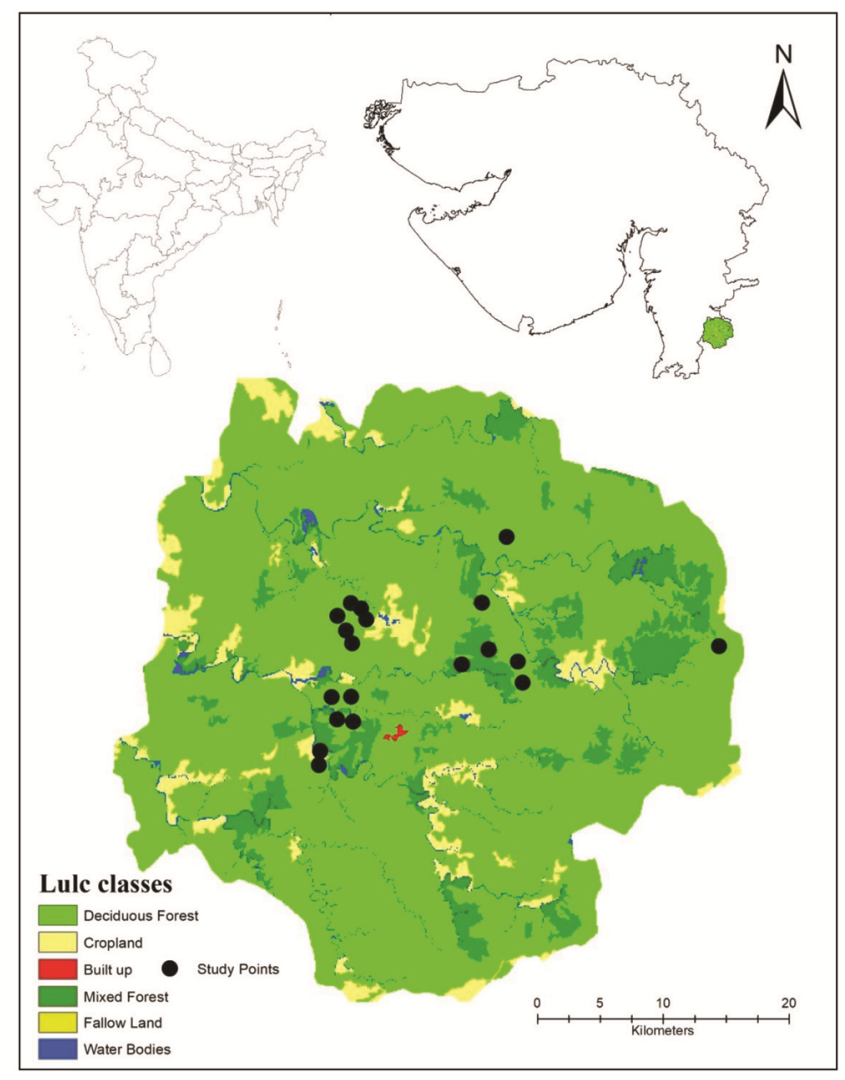

Figure 1. Study area map depicting land use classes and study sites. 
most parts of the area. The forests are mostly of deciduous type both moist and dry and a small portion being evergreen. They are continuous in all parts except at the places where the slopes are too steep to retain the soil and where biotic interference has cleared or opened it out. A significant area of Dang is a part of Purna Wildlife Sanctuary $\left(160.8 \mathrm{~km}^{2}\right)$ and Vansda National Park $\left(23.9 \mathrm{~km}^{2}\right)$. The Dang forests consist of plains belonging to Malabar region, hilly tract which are a part of Western Ghats as well as the coastal region alongside the Arabian sea, all of which extend to the state of Maharashtra. The diurnal range of variation in temperature does not exceed $5^{\circ} \mathrm{C}$. The temperature is not uniform throughout the district but varies with altitude. Annual minimum and maximum temperatures are around $10^{\circ} \mathrm{C}$ and $45^{\circ} \mathrm{C}$ (ref. 17). The climate can be said to be warm and dry for most of the year except during monsoon season which extends from June to September bringing out nearly all annual rainfall (1635 $\mathrm{mm}$ for 2011), thus being very supportive for vegetative growth.

Hard, impermeable Deccan trap basalt rock covers the entire district making the soils iron rich. In the areas of basalt lava flows, soils are black, clayey to loamy in texture and red coloured in some areas. However, the major portion of the district comprises of lateritic soils. Dark black to red sandy soils occupy some portions in both the west and east sides.

The study site includes 7 ranges, 4 in Dang north division and 3 in Dang south division. They were stratified into various compartments. Sampling of $0.002 \%$ was done and according to the area of each compartment, the number of $20 \mathrm{~m} \times 20 \mathrm{~m}$ quadrats to be laid was calculated. The nearest whole number was taken as the number of quadrats to be laid. The quadrats were laid using measuring tape and nail.

In each quadrat, all the trees were enumerated and measured for their girths. The individuals with girths greater than $10 \mathrm{~cm}$ were classified in five different girth classes, viz. 11-30, 31-60, 61-90, 91-200 and >200 cm. As girth class increases in proportion to age, the widening girth represents increasing age and thus this method is similar to chrono-sequence approach which is widely used to study forest growth processes for different tree species $^{13,18}$. The study was designed to harvest minimum trees with sufficient sample size to acquire information on species and size distribution in a forest. Hence, only one individual of each species from each girth class was selected for harvesting. The sample individuals with details of height, diameter, wood-specific gravity of the species (referred from global wood density database) ${ }^{19,20}$, above-ground and below-ground biomass are given in Table 1. All the species had at least one individual in each of the first four girth classes. Adina cordifolia was the exception with the individual missing in $61-90 \mathrm{~cm}$ girth class. No species showed presence of an individual in the highest girth class of $>200 \mathrm{~cm}$ except Adina cordi- folia. This indicated that this forest was second-growth or secondary forest as per the definition by FAO.

The selected individuals were completely uprooted and separated in 6 above-ground parts, viz. trunk, primary branches, secondary branches, twigs, leaves and fruits (if present) and roots as below-ground part. Thus, below ground biomass consisted only of roots, mostly coarse roots. Only Adina cordifolia showed the presence of fruits in the harvesting season which was near the onset of monsoon (the second week of June). The girth of trunk and primary branches and the lengths of trunk, primary and secondary branches were measured using measuring tape. The heavy parts for large trees, i.e. roots, trunk and branches were weighed using analytical balance with a precision of $10 \mathrm{~g}$ and the twigs, leaves and fruits were measured using analytical balance with a precision of $0.5 \mathrm{~g}$. Five hundred gram samples from all seven parts of each tree were analysed in the lab. The biomass was obtained after drying the samples in an oven at $70^{\circ} \mathrm{C}$ till constant weight was obtained. The percent dry weight of each sample was extrapolated to get the biomass of the whole part of the plant. The dried samples were crushed and powdered and sieved through $0.02 \mathrm{~mm}$. The carbon analysis was done using $\mathrm{C}, \mathrm{N}, \mathrm{H}, \mathrm{S}$ and $(\mathrm{O})$ analyser of Perkin Elmer, Model 2400 Series II.

There is limited literature already published on belowground biomass assessments from different types of forests around the world ${ }^{11}$. Some of the assumptions made here are that all the species are approximately in similar climatic and soil conditions and therefore the biomass and carbon content is characteristic of each of the species itself. To support our assumption, we tested the soil for its $\mathrm{pH}$, bulk density and organic carbon. The factors like bulk density, forest type, soil texture and $\mathrm{pH}$ of the soil that influence the SOC stock were also studied.

For developing allometric equations of biomass, all the harvested individuals which contain one individual of each girth class of each species were selected to give four representative samples for each species specific equation and 28 samples for multi-species regression equation. A

Table 1. Soil characteristics of selected site

\begin{tabular}{lccc}
\hline Range & Mean TOC\% & Mean pH & Mean BD $\left(\mathrm{g} / \mathrm{cm}^{3}\right)$ \\
\hline Singana & $0.50 \pm 0.22$ & $5.78 \pm 0.02$ & $1.15 \pm 0.06$ \\
Ahwa (W) & $1.30 \pm 0.80$ & $5.91 \pm 0.33$ & $1.21 \pm 0.12$ \\
Ahwa (East) & $1.50 \pm 0.34$ & $6.01 \pm 0.3$ & $1.18 \pm 0.04$ \\
Chikhali & $2.99 \pm 0.01$ & $5.45 \pm 0.01$ & $1.16 \pm 0.01$ \\
Ahwa (W) & $3.20 \pm 0.76$ & $5.58 \pm 0.26$ & $1.17 \pm 0.15$ \\
Ahwa (W) & $2.42 \pm 0.80$ & $5.35 \pm 0.01$ & $1.16 \pm 0.10$ \\
Loachali & $2.27 \pm 0.87$ & $5.76 \pm 0.36$ & $1.01 \pm 0.09$ \\
Ahwa (W) & $0.89 \pm 0.47$ & $5.95 \pm 0.01$ & $1.15 \pm 0.01$ \\
Singana & $1.7 \pm 0.63$ & $5.61 \pm 0.05$ & $1.17 \pm 0.01$ \\
Loachali & $2.28 \pm 0.21$ & $5.83 \pm 0.02$ & $1.17 \pm 0.06$ \\
Waghai & $3.32 \pm 0.23$ & $5.45 \pm 0.01$ & $1.17 \pm 0.01$ \\
Subir & $3.15 \pm 0.12$ & $5.99 \pm 0.05$ & $1.12 \pm 0.03$ \\
Subir & $1.95 \pm 0.15$ & $6.24 \pm 0.03$ & $0.75 \pm 0.05$ \\
\hline
\end{tabular}

TOC, Total organic carbon; BD, Bulk density; \pm , Standard error. 
set of local site-specific allometric equations were developed by using straight line equation as mentioned previously and applying the following pan-tropical allometric models to the empirical data ${ }^{19}$

$$
\ln \mathrm{AGB}=a+b(\ln D)+c(\ln D)^{2}+d(\ln D)^{3}+e(\ln \rho),
$$

$$
\ln \mathrm{AGB}=a+b \ln D+c(\ln H)+d(\ln \rho)
$$

where AGB, $D, \rho$ and $H$ are tree above-ground biomass (in $\mathrm{kg}$ ), diameter (in $\mathrm{cm}$ ), wood density (in $\mathrm{g} / \mathrm{cc}$ ) and height (in $\mathrm{m}$ ) respectively, and $a$ (the constant), $b, c, d$ and $e$ (co-efficient) are the model parameters. Equation (2) is a general model which is preferred when height is not available, as used by $\mathrm{Chave}^{21}$ (model II) while developing best fit pantropical equations. Equation (3) is a general model proposed first by Schumacher and Hall ${ }^{22}$. A wide variety of regression models have been developed and applied in different forest types and geographies ${ }^{7,23-26}$. The co-efficients were obtained by feeding the empirical values in the models. Log was applied on both sides to reduce the heteroscedasticity of data. The first three models are developed using straight line eq. (1) and general eq. (2). Local model 1 included only diameter as the independent variable and subsequently, variables $H$ and $\rho$ were added in subsequent local models 2 and 3 . This was done to observe the effect of each variable on the fitness of the model. Local models parallel to the 2 equations given by Chave for dry forests were developed and local coefficients were generated. All the equations were compared with parameters of goodness of fit, viz. significance $(P)$ value, coefficient of determination $\left(R^{2}\right)$ and residual standard error (RSE), also called as root mean squared error (RMSE).

Forest management strategies including a change in tree species affect the soil organic matter ${ }^{27,28}$ and hence, soil organic carbon and associated factors were measured. Table 1 puts light on carbon content of soils in the same plots from where the trees were sampled.

It can be observed that the maximum carbon content was seen in Waghai and Subir areas respectively, followed by Chikhali range. The carbon content ranged from $0.05 \%$ to $3.32 \%$ and the average carbon content was found to be $1.61 \%$. The highest carbon content was found in Waghai range which also showed highest bulk density of $1.69 \mathrm{~g} / \mathrm{cm}^{3}$. In general, it can be observed from the table that all the quadrats do not show a much significant difference in $\mathrm{pH}$, bulk density and soil organic carbon.

The above-ground parts were portioned into trunk, main branch, secondary branch, twigs and leaves while the below-ground biomass mainly consists of coarse roots. The proportion of biomass in stump and coarse roots did not show significant relation with girth. In all the plants, above-ground parts showed higher proportion of biomass than below-ground parts. However, we could only weigh the stump and coarse roots, which was the limitation of the study.

$S$. oleosa showed highest biomass in both girth classes 11-30 and 31-60 cm, B. retusa, C. graveolens showed highest in $61-90 \mathrm{~cm}$ and $A$. cordifolia showed highest biomass in girth class $91-200 \mathrm{~cm}$. This was probably due to their larger girths compared to others in the respective girth classes as the plants showing highest biomass values in any of the parts had highest girth in that range of girthclass. Commercial logging which selectively aims to cut tree species having higher wood densities, large GBH or high basal area likely lead to an overall decline in carbon storage of those forest regions by $70 \%, 29 \%$ and $17 \%$ respectively ${ }^{10}$.

A generic equation of stem biomass using diameter at breast height $(D)$, wood-specific gravity $(\rho)$ and height $(H)$ was determined for all species (Table 2$)$. The equations are represented with the $Y$-intercept, degree of free$\operatorname{dom}(\mathrm{d} f)$, coefficient of determination $\left(R^{2}\right)$, absolute sum of squares, residual standard error and $P$-value of different species. It was observed that total biomass of all the tree species showed positively significant correlation with square of diameter at breast height $(D)$ and height $(H)$. Wood density seemed to play a less significant role.

The estimation of above and below ground biomass pools is of great importance for characterization of structure and function of ecosystems ${ }^{19}$. One of the widely used approaches for modelling stand development dynamics is the chronosequence approach that allows study of forest growth processes for different tree species ${ }^{12,18}$. Girth is representative of age because it increases along with age. Thus, this method is on the lines of chronosequence approach. Biomass estimates from allometric equations also indicate the potential for $\mathrm{C}$ storage. Carbon accounting is thus directly dependent on biomass dynamics ${ }^{29,30}$ and hence, accurate information on biomass is very much needed. Developing local and regional models to provide better estimates of, specifically, total (both above-ground and below-ground) biomass ${ }^{28}$ serves this purpose. Therefore, these equations would help in estimating biomass of deciduous forests with greater accuracy on a larger scale.

Estimation of these existing carbon reservoirs would fill the knowledge gap of carbon stocks in tropical deciduous forests and thereby aid in decision- and policymaking processes regarding carbon management in forests. Thus, allometric equations obtained would be as helpful as the yield tables to estimate biomass and carbon sequestration potential of species, forest stands, forest types, etc. Therefore, development of regional allometric equations cannot be understated ${ }^{31}$.

From Table 3 it was found that local models with all three variables were a better fit than models with only diameter and diameter and height.

Table 4 shows a comparison of the biomass estimates of all trees obtained using local models and Chave models I and II using paired $t$-test. From Tables 3 and 4, 
RESEARCH COMMUNICATIONS

Table 2. Description of trees with their above-ground and below-ground biomass

\begin{tabular}{|c|c|c|c|c|c|c|c|c|}
\hline Range & Trees & Height (m) & $\mathrm{GBH}(\mathrm{cm})$ & $D(\mathrm{~cm})$ & $\rho(\mathrm{g} / \mathrm{cc})$ & AGB $(\mathrm{kg})$ & BGB (kg) & Total \\
\hline Loavchali & Adina cordifolia & 4.1 & 18.1 & 5.73 & 0.59 & 4.75 & 3.38 & 8.13 \\
\hline Ahwa (W) & Adina cordifolia & 6.0 & 37.2 & 11.78 & 0.59 & 20.93 & 9.88 & 30.81 \\
\hline Ahwa (W) & Adina cordifolia & 33.1 & 195.0 & 62.07 & 0.59 & 2248.01 & 521.23 & 2769.24 \\
\hline Waghai & Adina cordifolia & 36.2 & 235.3 & 74.80 & 0.59 & 2700.43 & 317.31 & 3017.74 \\
\hline Ahwa (W) & Bridelia retusa & 4.25 & 11.1 & 3.50 & 0.50 & 1.59 & 0.45 & 2.04 \\
\hline Ahwa (W) & Bridelia retusa & 8.0 & 45.3 & 14.32 & 0.50 & 39.74 & 10.8 & 50.54 \\
\hline Ahwa (E) & Bridelia retusa & 12.5 & 77.2 & 24.51 & 0.50 & 283.61 & 51.66 & 335.27 \\
\hline Subir & Bridelia retusa & 15.0 & 100.3 & 31.83 & 0.50 & 170.43 & 235.04 & 405.47 \\
\hline Loavchali & Casearia graveolens & 3.6 & 16.5 & 5.09 & 0.62 & 3.62 & 1.95 & 5.57 \\
\hline Ahwa (W) & Casearia graveolens & 6.5 & 40.3 & 12.73 & 0.62 & 14.81 & 12.76 & 27.57 \\
\hline Loavchali & Casearia graveolens & 12.1 & 81.1 & 25.78 & 0.62 & 262.08 & 71.02 & 333.09 \\
\hline Ahwa (W) & Casearia graveolens & 12.6 & 119.1 & 37.88 & 0.62 & 317.03 & 60.82 & 377.85 \\
\hline Singana & Dalbergia latifolia & 4.6 & 14.5 & 4.46 & 0.75 & 3.54 & 0.997 & 4.54 \\
\hline Singana & Dalbergia latifolia & 8.4 & 50.2 & 15.92 & 0.75 & 72.17 & 15.12 & 87.29 \\
\hline Singana & Dalbergia latifolia & 13.1 & 61.6 & 19.42 & 0.75 & 218.42 & 37.62 & 256.04 \\
\hline Subir & Dalbergia latifolia & 20.4 & 150.1 & 47.75 & 0.75 & 1551.19 & 317.19 & 1868.38 \\
\hline Singana & Ougeinia oojeinensis & 5.0 & 14.6 & 4.46 & 0.70 & 3.91 & 0.88 & 4.783 \\
\hline Ahwa (W) & Ougeinia oojeinensis & 7.8 & 54.5 & 17.19 & 0.70 & 56.01 & 14.97 & 70.98 \\
\hline Singana & Ougeinia oojeinensis & 10.0 & 67.3 & 21.33 & 0.70 & 206.10 & 43.90 & 250.00 \\
\hline Ahwa (W) & Ougeinia oojeinensis & 15.3 & 147 & 46.79 & 0.70 & 513.79 & 58.08 & 571.87 \\
\hline Ahwa (W) & Schleichera oleosa & 8.1 & 24.2 & 7.64 & 0.96 & 55.97 & 5.87 & 61.84 \\
\hline Ahwa (W) & Schleichera oleosa & 10.1 & 48.3 & 15.28 & 0.96 & 101.87 & 32.88 & 134.75 \\
\hline Ahwa (W) & Schleichera oleosa & 12.2 & 65.0 & 20.69 & 0.96 & 190.93 & 50.07 & 241.00 \\
\hline Ahwa (W) & Schleichera oleosa & 26.1 & 106.3 & 33.74 & 0.96 & 331.04 & 221.1 & 552.14 \\
\hline Ahwa (W) & Terminalia bellirica & 5.3 & 18.4 & 5.73 & 0.72 & 5.019 & 2.33 & 7.35 \\
\hline Loavchali & Terminalia bellirica & 13.5 & 43.5 & 13.69 & 0.72 & 102.98 & 17.17 & 120.15 \\
\hline Ahwa (W) & Terminalia bellirica & 15.2 & 73.0 & 23.24 & 0.72 & 217.44 & 57.68 & 275.12 \\
\hline Chikhali & Terminalia bellirica & 22.0 & 145.1 & 46.15 & 0.72 & 1299.55 & 172.25 & 1471.8 \\
\hline
\end{tabular}

Table 3. Local site-specific allometric equations

\begin{tabular}{|c|c|c|c|c|c|c|c|c|c|}
\hline & $a$ & $b$ & $c$ & $d$ & $e$ & $\mathrm{~d} f$ & $P$ (Sig value) & Adj. $R^{2}$ & RSE \\
\hline & $\ln \rho$ & $\ln D$ & $(\ln D)^{2}$ & $(\ln D)^{3}$ & & & & & \\
\hline \multicolumn{10}{|c|}{ Local model 1: $\ln \mathrm{AGB}=a+b \ln D^{2}$} \\
\hline$D^{2}$ & -2.288 & 1.188 & & & & 26 & $<0.001$ & 0.935 & 0.289 \\
\hline $\mathrm{SE}$ & 0.357 & 0.06 & & & & & & & \\
\hline \multicolumn{10}{|c|}{ Local model 2: $\ln \mathrm{AGB}=a+b \ln \left(D^{2} H\right)$} \\
\hline$D^{2} \mathrm{H}$ & -3.064 & 0.941 & & & & 26 & $<0.001$ & 0.941 & 0.259 \\
\hline \multicolumn{10}{|c|}{ Local model 3: $\ln \mathrm{AGB}=a+b \ln \rho+c \ln D+d \ln H$} \\
\hline$\rho, D, H$ & -2.159 & 1.218 & 2.163 & 0.41 & & 24 & $<0.001$ & 0.951 & 0.217 \\
\hline SE & 0.502 & 0.482 & 0.205 & 0.344 & & & & & \\
\hline \multicolumn{10}{|c|}{ Local model 4: $\ln \mathrm{AGB}=a+\ln (\rho \mathrm{DDH})$} \\
\hline$\rho \mathrm{DDH}$ & -2.678 & 0.938 & & & & 26 & $<0.001$ & 0.95 & 0.219 \\
\hline SE & 0.325 & 0.041 & & & & & & & \\
\hline \multicolumn{10}{|c|}{ Local model 5: $\ln \mathrm{AGB}=a+b \ln \rho+c \ln D+d(\ln D)^{2}+e(\ln D)^{3}$} \\
\hline SE & 3.272 & 0.499 & 3.922 & 1.477 & 0.175 & & & & \\
\hline
\end{tabular}

$\mathrm{d} f$, Degrees of freedom; $p$ value, significance value at 95\% confidence interval; RSE, Residual standard error; SE, Standard error; AGB, Aboveground biomass; Adj. $R^{2}$, Adjusted coefficient of determination.

it is clear that local model 3 with all the variables independently fitted performs the best of all equations (Figure 3 ). The pan-tropical models showed significant difference in estimation of AGB as shown by paired $t$-tests.

After analysing the mean carbon content of seven species using CNHS/O analyser, it was multiplied with the total biomass of the particular species in each girth class and maximum carbon stored by the individual plant species was obtained in each girth class (Table 3 ).

The mean carbon content in all tree species across different girth classes was analysed by pooling and averaging carbon content of all different parts of each species. The mean across all girth classes of selected plant species was found to be as depicted in Figure 2. 
RESEARCH COMMUNICATIONS

Table 4. Comparative analysis by paired $T$-test of equations

\begin{tabular}{|c|c|c|c|c|c|}
\hline & Models & RMSE & $t$ & $\mathrm{~d} f$ & Sig. (2-tailed) \\
\hline Local model 1 & $\ln \mathrm{AGB}=a+b \ln D^{2}$ & 2.753 & 0.2926 & 27 & 0.7721 \\
\hline Local model 2 & $\ln \mathrm{AGB}=a+b \ln \left(\left(D^{2}\right) H\right)$ & 2.594 & -0.0027 & 27 & 0.9978 \\
\hline \multicolumn{6}{|c|}{ Using all the three variables independently fitted } \\
\hline Local model 3 & $\ln \mathrm{AGB}=a+b \ln \rho+c \ln D+d \ln H$ & 2.29 & 0.3334 & 27 & 0.7414 \\
\hline \multirow[t]{2}{*}{ Pan-tropical model for dry forests } & & 2.294 & -3.6802 & 27 & 0.0010 \\
\hline & Models without height $H$ & & & & \\
\hline Pan-tropical model for dry forests & $\ln \mathrm{AGB}-\ln \mathrm{Chv} \mathrm{d} f$ & 3.846 & -6.2346 & 27 & 0.0000 \\
\hline Local model 4 & $\ln \mathrm{AGB}=a+b \operatorname{Ln} \rho D^{2} H$ & 2.392 & 0.1363 & 27 & 0.8926 \\
\hline
\end{tabular}

RMSE, Root mean squared error; $\mathrm{d} f$, Degrees of freedom.

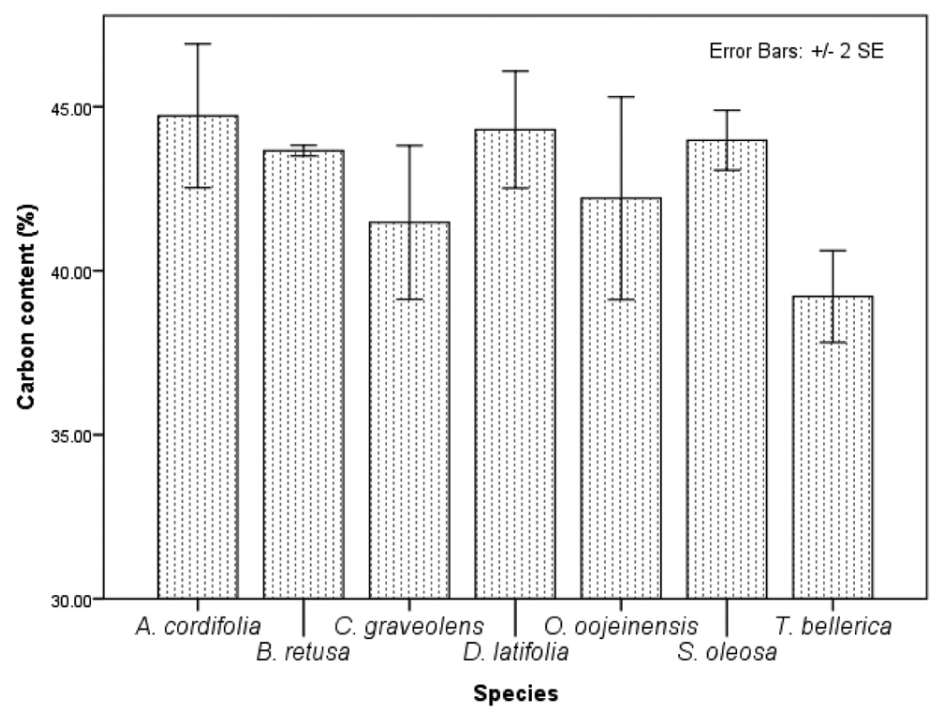

Figure 2. Mean carbon content of plants across all girth classes. SE, Standard error (represented by error bars).

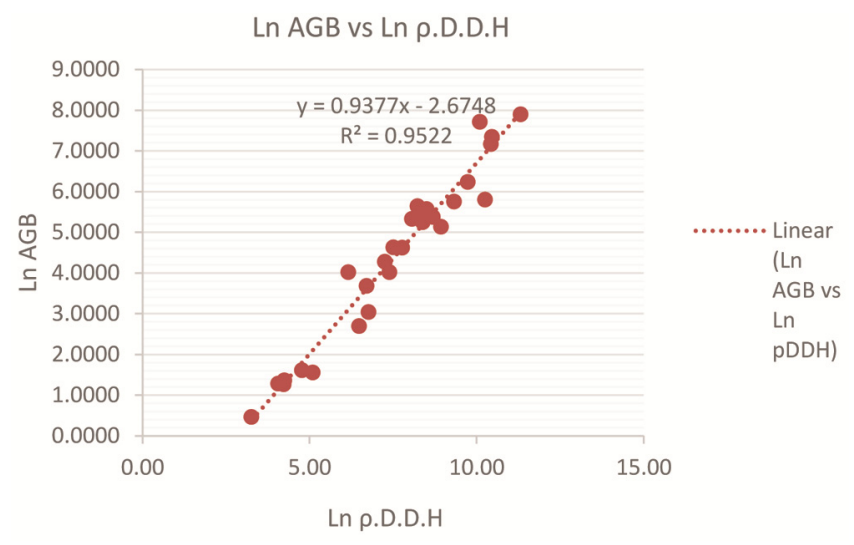

Figure 3. Scatter plot of best fit regression model.

To sequester higher carbon stocks, species having higher standing carbon stock and higher wood density and longer rotation periods must be planted more ${ }^{32}$. Thus, A. cordifolia shows the highest carbon sequestration potential while $T$. bellirica shows the least potential. Also, S. oleosa and D. latifolia have high wood densities,
$0.96 \mathrm{~kg} / \mathrm{cm}^{3}$ and $0.75 \mathrm{~kg} / \mathrm{cm}^{3}$, with $S$. oleosa having the highest among all the species. According to Bunker et $a l .^{33}$, planting species with higher wood densities increases the above-ground carbon storage by $75 \%$.

All the tree species showed a stored carbon percentage between $40 \%$ and $45 \%$. Adina cordifolia again dominated the other species by having nearly $45 \%$ carbon while $O$. oojeinensis and $S$. oleosa on an average possessed $44.29 \%$ and $43.98 \%$ carbon. These figures are close to the conventional conversion of biomass to carbon percentage of $45 \%$, as described by Singh and Singh ${ }^{34}$.

The increased interest in REDD + and CDM to promote afforestation and reforestation as an offset to greenhouse gas emissions has created more demand for biomass estimation models. The present study has generated primary baseline data in Gujarat on development of allometric relationships for biomass estimation and carbon sequestration of dominant economically important species. The results of this study are in accordance with the established pan tropical models, suggesting that inclusion of a larger number of the representative individuals and independent variables like local wood density would give 
more robust biomass estimates. The regression equations developed will be useful for regional estimation of biomass and carbon stocks of the state and same species in similar type of forests elsewhere.

1. Forests, T. I. N., Status and trends in forests and forestry. Carbon N. Y., 2007, 59-132.

2. Food and Agriculture Organization of the United Nations (FAO). REDD+ Reducing Emissions from Deforestation and Forest Degradation, 2017; http://www.fao.org/redd/en/ (accessed on 3 October 2017).

3. Stas, S. M., Rutishauser, E., Chave, J., Anten, N. P. R. and Laumonier, Y., Estimating the aboveground biomass in an old secondary forest on limestone in the Moluccas, Indonesia: Comparing locally developed versus existing allometric models. For. Ecol. Manage., 2007, 389, 27-34.

4. Houghton, R. A., Aboveground forest biomass and the global carbon balance. Glob. Chang. Biol., 2005, 11, 945-958.

5. Fayolle, A., Doucet, J. L., Gillet, J. F., Bourland, N. and Lejeune, P., Tree allometry in Central Africa: Testing the validity of pantropical multi-species allometric equations for estimating biomass and carbon stocks. For. Ecol. Manage., 2013, 305, 29-37.

6. Becknell, J. M., Kissing Kucek, L. and Powers, J. S., Aboveground biomass in mature and secondary seasonally dry tropical forests: A literature review and global synthesis. For. Ecol. Manage., 2012, 276, 88-95.

7. Basuki, T. M., van Laake, P. E., Skidmore, A. K. and Hussin, Y. A., Allometric equations for estimating the above-ground biomass in tropical lowland Dipterocarp forests. For. Ecol. Manage., 2009, 257, 1684-1694.

8. Clark, D. A., Are tropical forests an important carbon sink? Reanalysis of the long-term plot data. Ecol. Appl., 2002, 12, 3-7.

9. Singh, L. and Singh, J. S., Importance of short-lived components of a dry tropical forest for biomass production and nutrient cycling. J. Veg. Sci., 1993, 4, 681-686.

10. Chaturvedi, R. K., Raghubanshi, A. S. and Singh, J. S., Carbon density and accumulation in woody species of tropical dry forest in India. For. Ecol. Manage., 2011, 262, 1576-1588.

11. Dudley, N. S. and Fownes, J. H., Preliminary biomass equations for eight species of fast-growing tropical trees. J. Trop. For. Sci., 1992, 5, 68-73.

12. Cairns, M. A. et al., Root biomass allocation in the World's upland forests. Oecologia, 1997, 111, 1-11.

13. Peichl, M. and Arain, M. A., Allometry and partitioning of aboveand belowground tree biomass in an age-sequence of white pine forests. For. Ecol. Manage., 2007, 253, 68-80.

14. Singh, V., Tewari, A., Kushwaha, S. P. S. and Dadhwal, V. K., Formulating allometric equations for estimating biomass and carbon stock in small diameter trees. For. Ecol. Manage., 2011, 261, 1945-1949.

15. Gupta, B. K., The Dang District, Gujarat. Groundwater Brochure, Technical Report Series, Central Ground Water Board, Ministry of Water Resources, Government of India, 2014.

16. Centre for Environment Education, Perspective Plan for the Dangs.

17. Mistry, A., Lodha, P. P., Prakash, I. and Mehmood, K., Estimation of direct runoff for Purna river sub-basin, using SCS-CN method, Dangs district, Gujarat. Int. J. Adv. Eng. Res., 2017, 12, 581-593.

18. Uri, V. et al., Biomass production and carbon sequestration in a fertile silver birch (Betula pendula Roth) forest chronosequence. For. Ecol. Manage., 2012, 267, 117-126.

19. Chave, J., Coomes, D. A., Jansen, S., Lewis, S. L., Swenson, N. G. and Zanne, A. E., Towards a worldwide wood economics spectrum. Ecol. Lett., 2009, 12(4), 351-366; https://doi.org/10.1111/ j.1461-0248.2009.01285.x.
20. Zanne, A. E. et al., Data from: towards a worldwide wood economics spectrum. Dryad Digital Repository, 2009; https://doi. org/10.5061/dryad.234.

21. Chave, J. et al., Tree allometry and improved estimation of carbon stocks and balance in tropical forests. Oecologia, 2005, 145, 8799.

22. Schumacher, F. X. and Hall, F. S., Logarithmic expression of timber-tree volume. J. Agric. Res., 1933, 47, 719-734.

23. Brown, S. G. A. and Lugo, A. E., Biomass estimation methods for tropical forests with applications to forest inventory data. For. Sci., 1989, 35, 881.

24. Woodall, C. W., Heath, L. S., Domke, G. M. and Nichols, M. C., Methods and equations for estimating aboveground volume, biomass, and carbon for trees in the US forest inventory, GTR NRS-88, 2010, 34

25. El, P. et al., Improved allometric models to estimate the aboveground biomass of tropical trees. Glob. Chang. Biol., 2014, 20, 3177-3190.

26. Chaturvedi, R. K. and Raghubanshi, A. S., Allometric models for accurate estimation of aboveground biomass of teak in tropical dry forests of India. For. Sci., 2015, 61, 938-949.

27. Binkley, D., The influence of tree species on forest soils: processes and patterns. In Proceedings of the Trees and Soil Workshop, 1994, 33.

28. Jandl, R. et al., How strongly can forest management influence soil carbon sequestration? Geoderma, 2007, 137, 253-268.

29. Petrokofsky, G. et al., Comparison of methods for measuring and assessing carbon stocks and carbon stock changes in terrestrial carbon pools. How do the accuracy and precision of current methods compare? A systematic review protocol. Environ. Evid., 2012, 1, 6; https://doi.org/10.1186/2047-2382-1-6.

30. Qureshi, A., Pariva, B. R. and Hussain, S. A., A review of protocols used for assessment of carbon stock in forested landscapes. Environ. Sci. Policy, 2012, 16, 81-89.

31. Kuyah, S. et al., Allometric equations for estimating biomass in agricultural landscapes: I. Aboveground biomass. Agric. Ecosyst. Environ., 2012, 158, 216-224.

32. Sharma, C. M., Baduni, N. P., Gairola, S., Ghildiyal, S. K. and Suyal, S., Tree diversity and carbon stocks of some major forest types of Garhwal Himalaya, India. For. Ecol. Manage., 2010, 260, 2170-2179.

33. Bunker, F., Bradford, R. K., Perfecto, I., Phillips, O. L., Sankaran, M., Naeem, S. D. E. and DeClerck, J. C., Species loss and aboveground carbon storage in a tropical forest. Science, 2005, 310, 1029-1031.

34. Singh, L. and Singh, J., Species structure, dry matter dynamics and carbon flux of a dry tropical forest in India. Ann. Bot., 1991, 68, 263-273.

Received 8 March 2017; revised accepted 12 October 2018

doi: $10.18520 / \mathrm{cs} / \mathrm{v} 116 / \mathrm{i} 3 / 472-478$ 